\title{
Aplikasi Pendeteksi Tingkat Kesamaan Dokumen Teks: Algoritma Rabin Karp Vs. Winnowing
}

\author{
Sugiono $^{1}$, Herwin $^{2}$, Hamdani $^{3}$, Erlin $^{4 *}$ \\ ${ }^{1,4}$ Program Studi Teknik Informatika, STMIK Amik Riau \\ ${ }^{2}$ Program Studi Manajemen Informatika, STMIK Amik Riau \\ ${ }^{3}$ Program Studi Teknologi Informasi, STMIK Amik Riau \\ Jl. Purwodadi Indah, Km.10, Pekanbaru \\ e-mail: ${ }^{1}$ sugiono@ stmik-amik-riau.ac.id, ${ }^{2}$ herwin@ @stmik-amik-riau.ac.id, \\ 33hamdani@stmik-amik-riau.ac.id, ${ }^{4}$ erlin@ @stmik-amik-riau.ac.id
}

\begin{abstract}
Abstrak
Tindakan copy paste dokumen teks sering terjadi dalam penulisan karya ilmiah tanpa memberikan kredit kepada yang mempunyai dokumen teks tersebut. Tindakan melanggar kode etik ini disebabkan karena tersedianya fasilitas menyalin dan menempel teks pada aplikasi pengolah kata. Tujuan dari penelitian ini adalah untuk membangun sebuah aplikasi yang mampu mendeteksi tingkat kesamaan dokumen teks dengan terlebih dahulu membandingkan tingkat kehandalan dari dua algoritma pendeteksi kesamaan teks yaitu algoritma rabin-karp dan algoritma winnowing. Perbandingan dilakukan terhadap dua variabel yaitu tingkat kemampuan mendeteksi dan waktu pemrosesan. Hasil menunjukkan bawah algoritma winnowing lebih unggul dibandingkan algoritma rabin-karp dari sisi tingkat akurasi maupun dari sisi waktu pemrosesan.
\end{abstract}

Kata kunci: Rabin-Karp, Winnowing, Deteksi Plagiat, Kesamaan Teks

\begin{abstract}
The behavior of copy pastes the text document often occurs in scientific writing without giving credit to those who have the text document. The behavior of this missing code of conduct due to the availability of facility to copy and paste the text in a word processing application. The purpose of this study is to build an application that can detect the index of similarity of text documents by first comparing the level of reliability of the two text similarity algorithms, i.e., Rabin-Karp and Winnowing. The comparison is measured based on two variables; the level of capability of detecting and processing time. The result shows that Winnowing algorithm outperforms Rabin-Karp in term of both accuracy and processing time.
\end{abstract}

Keywords: Rabin-Karp, Winnowing, Plagiarism Detection, Text Similarity

\section{Pendahuluan}

Perkembangan teknologi informasi yang semakin canggih mengakibatkan kemudahan disegala bidang, termasuk dalam pencarian informasi. Hal ini juga berdampak kepada penyimpanan data dan prosesnya yang mengalami perkembangan secara signifikan sehingga memudahkan orang untuk menyimpan, mencari, dan mengolah data dengan cepat. Kemudahan yang ditawarkan oleh media seperti internet untuk mendapatkan informasi merupakan salah satu dampak positif dari kemajuan teknologi. Namun perkembangan tersebut tidak terlepas dari dampak negatif yang hampir tidak dapat dihindari, salah satunya adalah plagiarisme. Plagiarisme adalah tindakan penyalahgunaan, dalam hal mencuri serta mempublikasikan 
pemikiran, bahasa, gagasan, ide atau ekspresi penulis lain dan merepresentasikan semua itu sebagai milik sendiri [1].

Praktek plagiat mudah terjadi diberbagai kalangan yang selalu berinteraksi dengan komputer mengingat adanya fasilitas untuk menyalin dan menempel teks (copy paste). Praktek ini lebih meningkat lagi dengan adanya dukungan fasilitas koneksi yang memungkinkan untuk mengakses hasil karya orang lain secara bebas melalui internet. Plagiarisme dapat mematikan kreatifitas seseorang karena tindakan ini tidak membutuhkan tenaga dan tidak harus berfikir keras. Oleh karena itu, tindakan preventif terhadap praktek plagiarisme harus dilakukan.

Membangun sebuah aplikasi yang dapat mendeteksi kesamaan dokumen teks menjadi penting untuk dilakukan. Saat ini tersedia beberapa aplikasi dan tools gratis maupun berbayar yang mampu mendeteksi kesamaan teks seperti Turnitin [2], Plagiarism Checker X [3], Grammarly [4], Dupli Checker [5] dan lainnya. Selanjutnya, beberapa penelitipun telah melakukan penelitian dengan menerapkan beberapa algoritma untuk mendeteksi tingkat kesamaan dokumen teks, seperti algoritma Brute-Force [6,7], Edit Distance [8,9], Boyer Moore [10,11] yang diimplementasikan untuk perbandingan teks lengkap. Selain itu, peneliti lain fokus pada tipe dokumen fingerprint yang digunakan untuk mendeteksi keakuratan salinan dokumen baik semua teks maupun sebagian. Algoritma yang termasuk dalam kelompok ini adalah algoritma Rabin-Karp $[12,13,14]$ dan algoritma Winnowing [15,16,17].

Penelitian ini akan membangun sebuah aplikasi yang mampu mendeteksi tingkat kesamaan dokumen teks dalam bahasa Indonesia dengan ekstensi doc, html dan pdf. Aplikasi dibangun dengan membandingkan dua algoritma yaitu algoritma Rabin-Karp dan Algoritma Winnowing yang termasuk kedalam kelompok dokumen fingerprint. Kedua algoritma akan dibandingkan berdasarkan kinerja evaluasi terhadap dua variabel yaitu tingkat akurasi dan waktu yang diperlukan dalam proses mendeteksi kesamaan dokumen teks. Aplikasi dapat menentukan indeks plagiat berdasarkan tingkat kesamaan penggunaan kata yang muncul pada dua dokumen berurutan.

\section{Metode Penelitian}

Tahapan pembuatan aplikasi pendeteksi kesamaan teks berdasarkan perbandingan kedua algoritma ini dimulai dari tahap menyediaan dokumen asli dan dokumen uji. Dokumen uji selanjutnya akan diproses berdasarkan tahapan preprocessing yaitu melakukan analisis semantik (kebenaran arti) dan analisis sintaktik (kebenaran susunan) terhadap teks. Tujuan dari pemrosesan awal ini untuk mempersiapkan teks menjadi data yang akan diproses lebih lanjut. Hasil dari preprocessing dilanjutkan dengan membuat $\mathrm{K}$ Gram, selanjutnya konversi K-Gram ke nilai hash. Untuk algoritma Rabin-Karp dilanjutkan dengan memilih nilai hash, sementara untuk algoritma winnowing dilanjutkan dengan meng-create window dan memilih hash minimum dengan indeks. Gambar 1 memperlihatkan perbandingan alur kerja dari kedua algoritma.

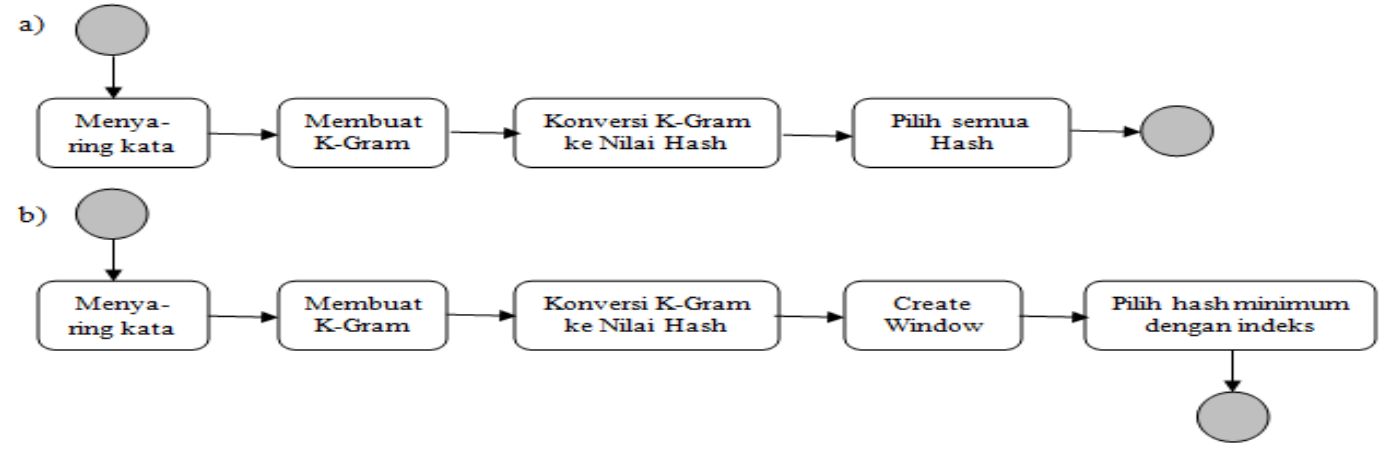

Gambar 1. a) Algoritma Rabin-Karp; b) Algoritma Winnowing 


\subsection{Pengujian Menggunakan Algoritma Rabin-Karp}

Beberapa tahapan yang dilakukan untuk pengujian kesamaan dokumen teks dengan algoritma Rabin-Karp diuraikan sebagai berikut:

(a) Langkah Pertama

Tabel 1 memperlihatkan persiapan dokumen yang akan diuji dengan algoritma Rabin-Karp.

Tabel 1. Dokumen Asli dan Dokumen Uji

\begin{tabular}{lll}
\hline Proses & Dokumen Asli & Dokumen Uji \\
\hline Isi String & $\begin{array}{l}\text { Salah satu Mahasiswa } \\
\text { "STMIK AMIK RIAU" } \\
\text { adalah sugiono }\end{array}$ & $\begin{array}{l}\text { sugiono Mahasiswa "STMIK } \\
\text { AMIK RIAU" }\end{array}$ \\
\hline
\end{tabular}

(b) Langkah Kedua

Case folding digunakan untuk mengubah seluruh huruf kapital menjadi huruf kecil, hanya huruf "a" sampai "z" seperti diperlihatkan pada tabel 2.

Tabel 2. Case Folding

\begin{tabular}{lll}
\hline Proses & Dokumen Asli & Dokumen Uji \\
\hline Isi String & salah satu mahasiswa & sugiono Mahasiswa \\
& "STMIK AMIK RIAU" adalah & "STMIK AMIK RIAU" \\
Case Folding & sugiono & \\
& $\begin{array}{l}\text { salah stmik amik riau" } \\
\text { adalah sugiono }\end{array}$ & "stmik amik riau" \\
& sugiono mahasiswa \\
\hline
\end{tabular}

(c) Langkah Ketiga

Membuang semua tanda baca yang ada pada dokumen termasuk enter dan spasi. Hasil langkah 3 dapat dilihat pada tabel 3.

Tabel 3. Membuang Tanda Baca

\begin{tabular}{|c|c|c|}
\hline Proses & Dokumen Asli & Dokumen Uji \\
\hline Isi String & $\begin{array}{l}\text { Salah satu Mahasiswa } \\
\text { "STMIK AMIK RIAU" } \\
\text { adalah sugiono }\end{array}$ & $\begin{array}{l}\text { sugiono Mahasiswa } \\
\text { "STMIK AMIK RIAU" }\end{array}$ \\
\hline Case Folding & $\begin{array}{l}\text { salah satu mahasiswa } \\
\text { "stmik amik riau" adalah sugiono }\end{array}$ & $\begin{array}{l}\text { sugiono mahasiswa } \\
\text { "stmik amik riau" }\end{array}$ \\
\hline $\begin{array}{l}\text { Buang Tanda } \\
\text { Baca }\end{array}$ & $\begin{array}{l}\text { Salahsatumahasiswastmikamik } \\
\text { riauadalahsugiono }\end{array}$ & sugionomahasiswastmikamikriau \\
\hline
\end{tabular}

(d) Langkah Keempat

Memotong string sepanjang $k$, untuk hasil $K$-Gram pertama sebanyak $k$. Untuk $K$ Gram selanjutnya diawali dari karakter kedua dari $K$-Gram yang pertama, sebanyak $k$. Misalnya nilai $k=5$. Tabel 4 memperlihatkan potongan sebahagian K-Gram dari algoritma Rabin Karp. 
Tabel 4. Cuplikan K-Gram Rabin-Karp

\begin{tabular}{|c|c|c|}
\hline \multirow{10}{*}{$\begin{array}{l}\text { Proses } \\
\text { K-Gram }\end{array}$} & Dokumen Asli & Dokumen Uji \\
\hline & $\{$ salah $\}\{$ alahs $\}$ & $\{$ sugio $\}\{$ ugion $\}$ \\
\hline & $\{$ lahsa $\}\{$ ahsat $\}$ & $\{$ giono $\}\{$ ionom $\}$ \\
\hline & $\{$ hsatu $\}\{$ satum $\}$ & $\{$ onoma $\}\{$ nomah $\}$ \\
\hline & $\{$ atuma $\}\{$ tumah $\}$ & $\{$ omaha $\}\{$ mahas $\}$ \\
\hline & $\{$ umaha $\}$ hasis $\}$ & $\{$ ahasi $\}\{$ hasis $\}$ \\
\hline & $\{$ asisw $\}\{$ siswa $\}$ & $\{$ asisw $\}\{$ siswa $\}$ \\
\hline & $\{$ iswas $\}\{$ swast $\}$ & $\{$ iswas $\}\{$ swast $\}$ \\
\hline & $\{$ waste $\}\{$ astem $\}$ & $\{$ waste $\}\{$ astem $\}$ \\
\hline & $\{$ stemi $\}\{$ temik $\}$ & $\{$ stemi $\}\{$ temik $\}$ \\
\hline
\end{tabular}

(a) Langkah Kelima

Tabel 5 memperlihatkan hashing terhadap seluruh pecahan string hasil dari proses parsing K-Gram.

Tabel 5. Proses Hashing

\begin{tabular}{llllr}
\hline Proses & Dokumen Asli & & Dokumen Uji & \\
\hline Hashing & $\{1827061\}$ & $\{1576921\}$ & $\{1853171\}$ & $\{1864126\}$ \\
& $\{1724281\}$ & $\{1573699\}$ & $\{1662530\}$ & $\{1699686\}$ \\
& $\{1688859\}$ & $\{1828254\}$ & $\{1786288\}$ & $\{1772611\}$ \\
& $\{1590026\}$ & $\{1868443\}$ & $\{1783208\}$ & $\{1738742\}$ \\
& $\{1871054\}$ & $\{1738742\}$ & $\{1571708\}$ & $\{1666956\}$ \\
& $\{1571708\}$ & $\{1666956\}$ & $\{1587331\}$ & $\{1838791\}$ \\
& $\{1587331\}$ & $\{1838791\}$ & $\{1705951\}$ & $\{1855222\}$ \\
& $\{1705951\}$ & $\{1855222\}$ & $\{1886678\}$ & $\{1588498\}$ \\
& $\{1886678\}$ & $\{1588498\}$ & $\{1851636\}$ & $\{1847238\}$ \\
& $\{1851636\}$ & $\{1847238\}$ & $\{1637799\}$ & $\{1749747\}$ \\
& $\{1637799\}$ & $\{1749747\}$ & $\{1692763\}$ & $\{1710145\}$ \\
& $\{1692763\}$ & $\{1710145\}$ & $\{1579252\}$ & $\{1749930\}$ \\
& $\{1579252\}$ & $\{1749930\}$ & $\{1694768\}$ & $\{1732210\}$ \\
& $\{1694768\}$ & $\{1732210\}$ & & \\
& $\{1821950\}$ & $\{1681736\}$ & & \\
& $\{1588838\}$ & $\{1855379\}$ & & \\
& $\{1566299\}$ & $\{1607446\}$ & & \\
& $\{1576921\}$ & $\{1724301\}$ & & \\
& $\{1573906\}$ & $\{1691124\}$ & & \\
& $\{1853171\}$ & $\{1864126\}$ & & \\
& $\{1662530\}$ & & & \\
\hline
\end{tabular}

(b) Langkah Keenam

Fingerprint adalah proses membandingkan string dari dokumen teks yang berbeda yang mempunyai hash value yang sama. Proses fingerprint diperlihatkan pada tabel 6 .

Tabel 6. Proses Fingerprint

\begin{tabular}{|l|llllll|}
\hline Finger print & $\{1738742\}$ & $\{1571708\}$ & $\{1666956\}$ & $\{1587331\}$ & $\{1838791\}$ \\
& $\{1705951\}$ & $\{1855222\}$ & $\{1886678\}$ & $\{1588498\}$ & $\{1851636\}$ \\
& $\{1847238\}$ & $\{1637799\}$ & $\{1749747\}$ & $\{1692763\}$ & $\{1710145\}$ \\
& $\{1579252\}$ & $\{1749930\}$ & $\{1694768\}$ & $\{1732210\}$ & $\{1853171\}$ \\
& $\{1864126\}$ & $\{1662530\}$ & & & \\
\hline
\end{tabular}


(c) Langkah Ketujuh

Similarity digunakan sebagai acuan tingkat kesamaan antara dokumen asli dengan dokumen uji. Tabel 7 memperlihatkan hasil similarity index sebesar $65.67 \%$ yang menandakan bahwa tingkat kemiripan dokumen asli dengan dokumen uji sebesar $65.67 \%$ dengan waktu proses selama 0,09 detik.

Tabel 7. Similarity Rabin-Karp

\begin{tabular}{|l|l|}
\hline Similarity Index & $65.67 \%$ \\
\hline Waktu & 0.09 Detik \\
\hline
\end{tabular}

\subsection{Pengujian Menggunakan Algoritma Winnowing}

Tahapan preprocessing sebagaimana yang telah dilakukan pada algoritma RabinKarp juga dilakukan pada algoritma Winnowing. Lanjutan proses memotong string sepanjang $k$ dalam proses perhitungan $K$-Gram dan lanjutan proses Hashing terhadap seluruh pecahan string juga sama antara kedua algoritma. Perbedaannya terletak langkah keenam dimana algoritma Winnowing tidak menggunakan semua nilai hash dari setiap rangkaian gram yang dibentuk. Nilai hash yang dibentuk pada tahap sebelumnya akan dibagi ke dalam window berukuran $w$. Window pertama berisi nilai hash pertama sampai nilai hash ke-w. Window kedua dibentuk dari nilai hash kedua sampai nilai hash ke-w+1 dan seterusnya sampai terbentuk window dari seluruh nilai hash. Pembentukan window dari hasil perhitungan nilai hash pada tahap sebelumnya dengan ukuran lebar window (w) $=6$ diperlihatkan pada tabel 8 .

Tabel 8. Cuplikan Window Winnowing

\begin{tabular}{|c|c|}
\hline Dokumen Asli & Dokumen Uji \\
\hline$\{1827061\}$ & $\{1853171\}\{1864126\}\{1662530\}$ \\
\hline$\{1573699\}\{1688859\}\{1828254\}$ & $\{1699686\}\{1786288\}\{1772611\}$ \\
\hline$\{1576921\} \quad\{1724281\} \quad\{1573699\}$ & $\{1864126\}\{1662530\}\{1699686\}$ \\
\hline$\{1688859\}\{1828254\}\{1590026\}$ & $\{1786288\}\{1772611\}\{1783208\}$ \\
\hline$\{1724281\} \quad\{1573699\} \quad\{1688859\}$ & $\{1662530\}\{1699686\}\{1786288\}$ \\
\hline$\{1828254\}\{1590026\}\{1868443\}$ & $\{1772611\}\{1783208\}\{1738742\}$ \\
\hline$\{1573699\} \quad\{1688859\} \quad\{1828254\}$ & $\{1699686\}\{1786288\}\{1772611\}$ \\
\hline$\{1590026\}\{1868443\}\{1871054\}$ & $\{1783208\}\{1738742\}\{1571708\}$ \\
\hline$\{1688859\} \quad\{1828254\} \quad\{1590026\}$ & $\{1786288\}\{1772611\}\{1783208\}$ \\
\hline$\{1868443\}\{1871054\}\{1738742\}$ & $\{1738742\}\{1571708\}\{1666956\}$ \\
\hline$\{1828254\} \quad\{1590026\} \quad\{1868443\}$ & $\{1772611\}\{1783208\}\{1738742\}$ \\
\hline$\{1871054\}\{1738742\}\{1571708\}$ & $\{1571708\}\{1666956\}\{1587331\}$ \\
\hline$\{1590026\} \quad\{1868443\} \quad\{1871054\}$ & $\{1783208\}\{1738742\}\{1571708\}$ \\
\hline$\{1738742\}\{1571708\}\{1666956\}$ & $\{1666956\}\{1587331\}\{1838791\}$ \\
\hline$\{1871054\} \quad\{1738742\}$ & $\{1738742\}\{1571708\}\{1666956\}$ \\
\hline$\{1571708\}\{1666956\}\{1587331\}$ & $\{1587331\}\{1838791\}\{1705951\}$ \\
\hline
\end{tabular}

Setelah terbentuk window dari seluruh nilai hash, tahap selanjutnya adalah menentukan nilai fingerprint teks dengan memilih nilai hash terkecil dari setiap window. Pemilihan nilai fingerprint dari hasil pembentukan window pada tahap sebelumnya diperlihatkan pada tabel 9. 
Tabel 9. Cuplikan Fingerprint Winnowing

\begin{tabular}{|c|c|}
\hline Dokumen Asli & Dokumen Uji \\
\hline$\{1827061\} \quad\{1576921\}$ & $\{1853171\} \quad\{1864126\} \quad\{1662530\}$ \\
\hline$\{1573699\}\{1688859\}\{1828254\}$ & $\{1699686\}\{1786288\}\{1772611\}$ \\
\hline$\{1576921\} \quad\{1724281\} \quad\{1573699\}$ & $\{1864126\} \quad\{1662530\} \quad\{1699686\}$ \\
\hline$\{1688859\}\{1828254\}\{1590026\}$ & $\{1786288\}\{1772611\}\{1783208\}$ \\
\hline$\{1724281\} \quad\{1573699\} \quad\{1688859\}$ & $\{1662530\} \quad\{1699686\} \quad\{1786288\}$ \\
\hline$\{1828254\}\{1590026\}\{1868443\}$ & $\{1772611\}\{1783208\}\{1738742\}$ \\
\hline$\{1573699\} \quad\{1688859\} \quad\{1828254\}$ & $\{1699686\} \quad\{1786288\} \quad\{1772611\}$ \\
\hline$\{1590026\}\{1868443\}\{1871054\}$ & $\{1783208\}\{1738742\}\{1571708\}$ \\
\hline$\{1688859\} \quad\{1828254\} \quad\{1590026\}$ & $\{1786288\} \quad\{1772611\} \quad\{1783208\}$ \\
\hline$\{1868443\}\{1871054\}\{1738742\}$ & $\{1738742\}\{1571708\}\{1666956\}$ \\
\hline$\{1590026\} \quad\{1868443\}$ & $\{1772611\} \quad\{1783208\} \quad\{1738742\}$ \\
\hline$\{1871054\}\{1738742\}\{1571708\}$ & $\{1571708\}\{1666956\}\{1587331\}$ \\
\hline$\{1590026\} \quad\{1868443\} \quad\{1871054\}$ & $\{1783208\}\{1738742\}\{1571708\}$ \\
\hline$\{1738742\}\{1571708\}\{1666956\}$ & $\{1666956\}\{1587331\}\{1838791\}$ \\
\hline$\{1868443\} \quad\{1871054\} \quad\{1738742\}$ & $\{1738742\}\{1571708\}\{1666956\}$ \\
\hline$\{1571708\}\{1666956\}\{1587331\}$ & $\{1587331\}\{1838791\}\{1705951\}$ \\
\hline
\end{tabular}

Nilai fingerprint yang dibentuk dari algoritma Winnowing digunakan untuk mengukur presentase kemiripan. Tabel 10 memperlihatkan similarity winnowing yang dihasilkan.

Tabel 10. Similarity Winnowing

\begin{tabular}{lllc}
\hline Dokumen Asli & \multicolumn{2}{l}{ Dokumen Uji } & \\
\hline$\{1573699\}\{1590026\}$ & $\{1571708\}$ & $\{1853171\}$ & $\{1662530\}$ \\
$\{1587331\}\{1588498\}\{1692763\}$ & $\{1571708\}$ & $\{1587331\}$ \\
$\{1579252\}\{1588838\}\{1566299\}$ & $\{1588498\}$ & $\{1637799\}$ \\
$\{1573906\}$ & & $\{1579252\}$ & \\
$=10$ & $=7$ & \\
\hline
\end{tabular}

$$
\begin{aligned}
& =\frac{\text { Jumlah_fingerprint_yang_sama }}{\text { Jumlah_seluruh_fingerprint }} 100 \% \\
& =\frac{y}{10} 100 \%=70 \%
\end{aligned}
$$

Berdasarkan hasil kesamaan kedua fingerprint, maka presentase kemiripan teks antara teks 1 dan teks 2 yang terbentuk yaitu sebesar $70 \%$.

\section{Hasil dan Pembahasan}

Tampilan output program aplikasi terdiri dari tampilan halaman utama program aplikasi, halaman data laporan dan halaman preview.

\subsection{Tampilan Halaman Utama}

Tampilan halaman utama program aplikasi adalah sebuah informasi tentang pengertian masing-masing algoritma dan cara pemakaian aplikasi. Gambar 2 adalah tampilan dari halaman utama program aplikasi yang telah dibangun yang terdiri atas menu home, upload bahan dan laporan. 


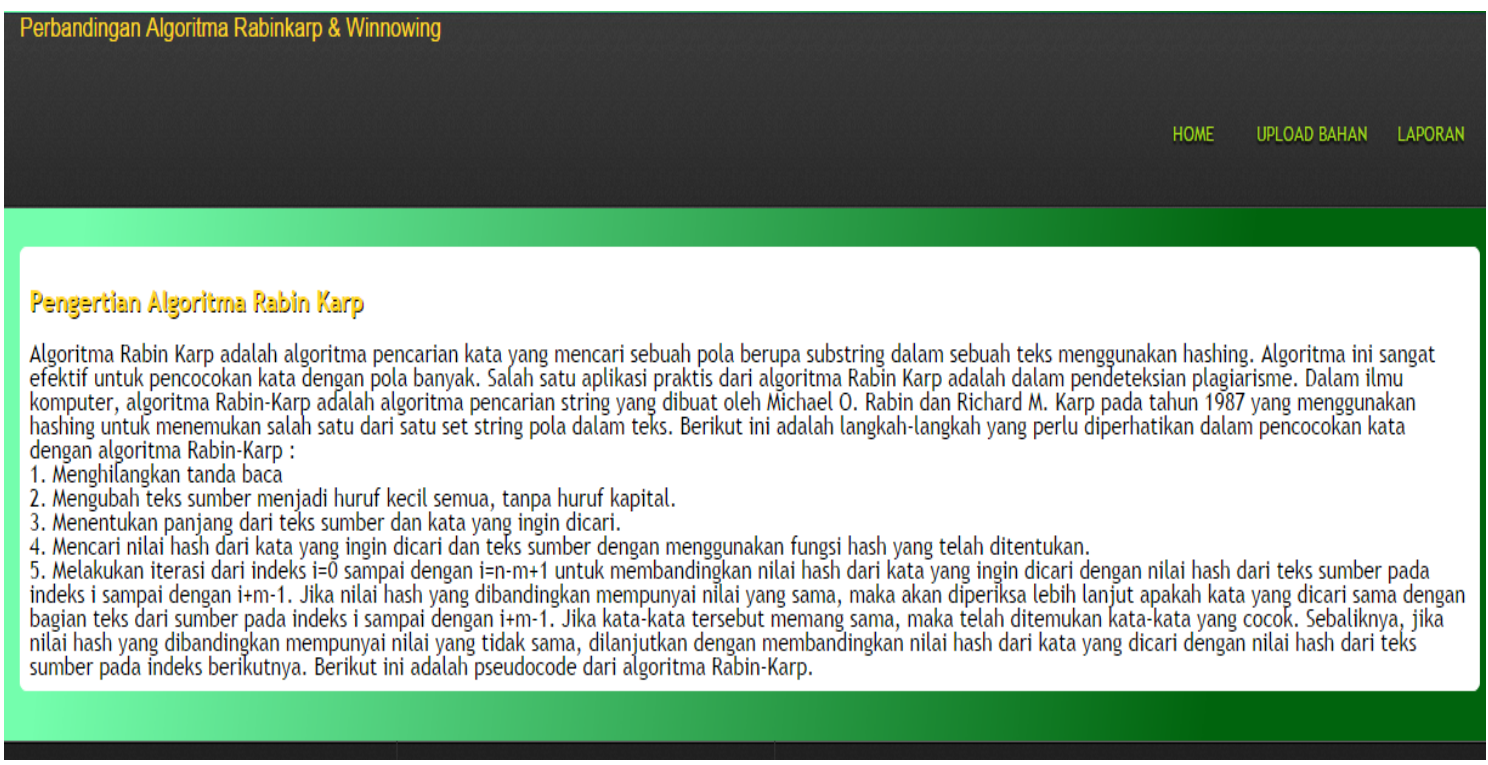

Gambar2: Tampilan halaman utama (interface)

\subsection{Tampilan Halaman Data Laporan}

Pada halaman history ditampilkan semua file hasil pengujian, memperlihatkan nama file asli dan file uji, persentase kemiripan teksnya (similarity text), serta hasil waktu yang diperlukan untuk memproses dari masing-masing metode. Kemudian pada halaman ini terdapat kontrol untuk melihat detail hasil pengujian dan kontrol untuk menghapus file hasil pengujian. Gambar 3 memperlihatkan tampilan halaman data laporan

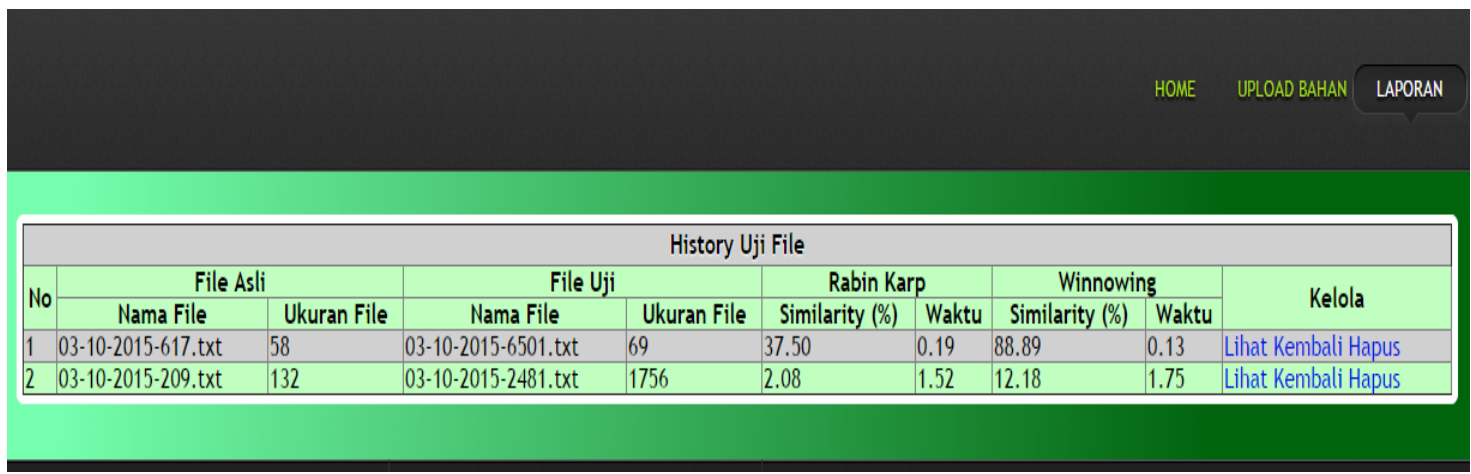

Gambar 3. Tampilan Halaman Data Laporan

\subsection{Tampilan Halaman Preview}

Pada kontrol "Lihat Kembali" akan ditampilkan halaman preview. Dimana data yang sudah kita proses diawal dapat kita lihat kembali tahapan-tahapannya, sehingga memberikan informasi yang kita butuhkan. Berikut tampilan sebagian halaman preview. 


\section{a) String}

Pada halaman ini akan ditampilkan hasil proses preprocessing yang terdiri dari case folding, tokenizing, filtering dari file asli dan file uji, sehingga pada tampilan ini akan tampak perbedaan tahap per tahap yang dilewati pada proses pendeteksian dokumen teks. Gambar 4 berikut ini adalah tampilan untuk string

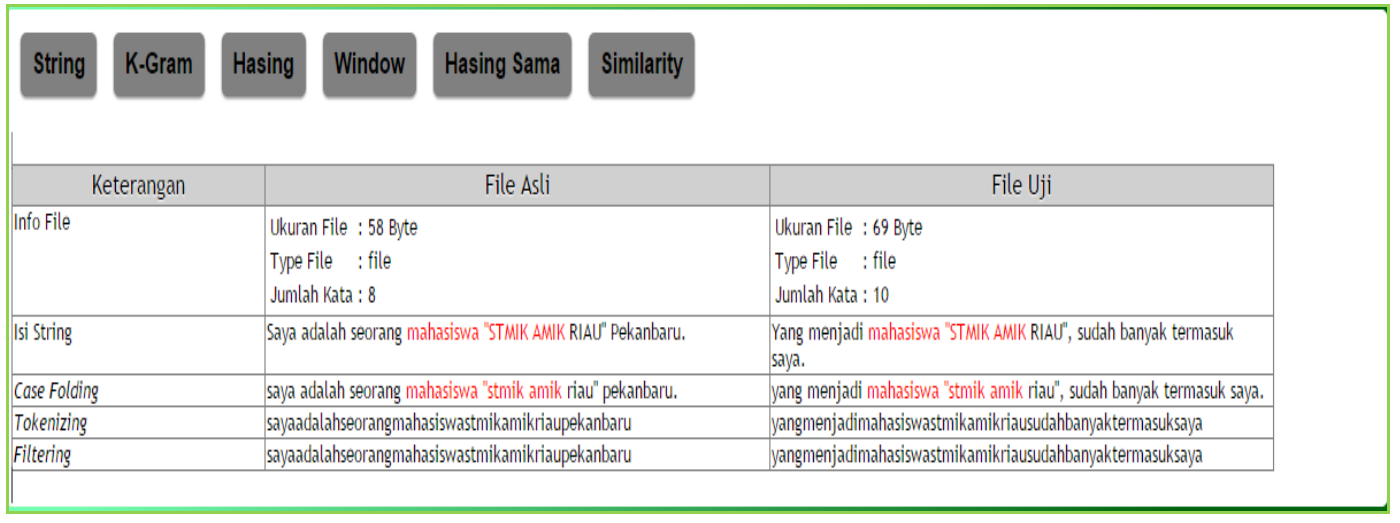

Gambar 4: Tampilan Halaman String

\section{b) $K$-Gram}

Tampilan proses pembentukan $K$-Gram dari masing-masing dokumen ditampilkan pada gambar 5 yang memperlihatkan dokumen asli dan dokumen uji. Tahap ini adalah proses pemotongan karakter sebanyak nilai $k$ ( $K$-Gram) yang sudah ditentukan, dan apabila terdapat kata yang sama dari pemotongan $K$-Gram tersebut langsung diberikan tanda merah

\begin{tabular}{|c|c|c|c|c|c|c|}
\hline String & K.Gram & Hasing & Window & Hasing Sama & Similarity & \\
\hline & Keterangan & & \multicolumn{3}{|c|}{ File Asli } & File Uji \\
\hline K.Gram & & & \multicolumn{3}{|c|}{ 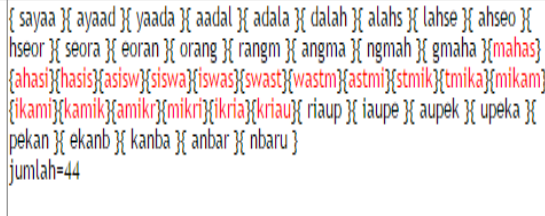 } & 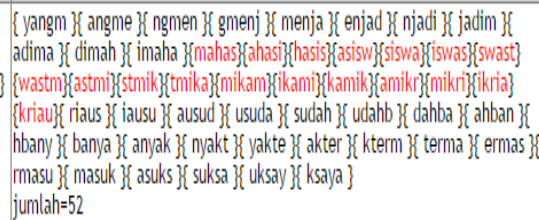 \\
\hline
\end{tabular}

\section{Gambar 5: Tampilan Halaman $K$-Gram}

\section{c) Hashing}

Pada halaman ini ditampilkan hasil proses hashing. Dimana pada proses ini, hasil K-Gram dicari nilai ASCIInya kemudian dihitung dengan rumus hash yang sudah dijabarkan pada bagian 2.1 sehingga menghasilkan angka-angka seperti yang diperlihatkan pada gambar 6 


\begin{tabular}{|c|c|c|c|c|c|c|}
\hline String & K-Gram & Hasing & Window & Hasing Sama & Similarity & \\
\hline & Keterangan & & \multicolumn{3}{|c|}{ File Asli } & File Uji \\
\hline Hash & & & $\begin{array}{l}\{1828627\}\{1594132\} \\
\{1724285\}\{\{15737383\} \\
\{150346\}\{1761963\} \\
\{1838791\}\{1705951\} \\
\{1749747\}\{1692763\} \\
\{1821965\}\{1681902\} \\
\{1579626\}\{1754056\} \\
\text { jumlah }=52\end{array}$ & $\begin{array}{l}\{1913602\}\{1562559\} \\
\{1689285\}\{1832928\} \\
\{1666080\}\{1738742\} \\
\{1855222\}\{1886686\} \\
\{1710145\}\{1579252\} \\
\{1590674\}\{1875564\}\end{array}$ & $\begin{array}{l}1566299\}\{1607446\}\{1576921\} \\
1641453\}\{1789935\}\{1812733\} \\
1571708\}\{1666956\}\{1587331\} \\
1588582\}\{1852562\}\{1857414\} \\
11749930\}\{1694768\}\{1732210\} \\
1788347\}\{1634203\}\{1710179\}\end{array}$ & $\begin{array}{l}\{1915220\}\{1580350\}\{1762013\}\{1666639\}\{\{1744873\}\{1639144\}\{1764538) \\
\{1694417\}\{1567278\}\{1618215\}\{1695362\}\{1738742\}\{1571708\}\{1666956) \\
\{1587331\}\{1838791\}\{1705951\}\{1855222\}\{1886686\}\{1588582\}\{1852562) \\
\{1857414\}\{1749747\}\{1692763\}\{1710145\}\{1579252\}\{1749930\}\{1694768) \\
\{1732210\}\{1821968\}\{1681951\}\{1591206\}\{1881416\}\{1852713\}\{1859076) \\
\{1606966\}\{1571636\}\{1666170\}\{1578663\}\{1582402\}\{1784591\}\{1914992\} \\
\{1577855\}\{1734567\}\{1847877\}\{1644846\}\{1827272\}\{1740285\}\{1588691\} \\
\{1853751\}\{1870517\}\{1732817\} \\
\text { jumlah=52 }\end{array}$ \\
\hline
\end{tabular}

Gambar 6: Tampilan Halaman Hashing

\section{d) Windows}

Gambar 7 memperlihatkan halaman proses window, yaitu memecah nilai hashing yang sama dengan menentukan berapa window yang akan di proses. Proses ini hanya dilakukan pada algoritma winnowing. Window yang digunakan adalah 4 window untuk masing-masing proses

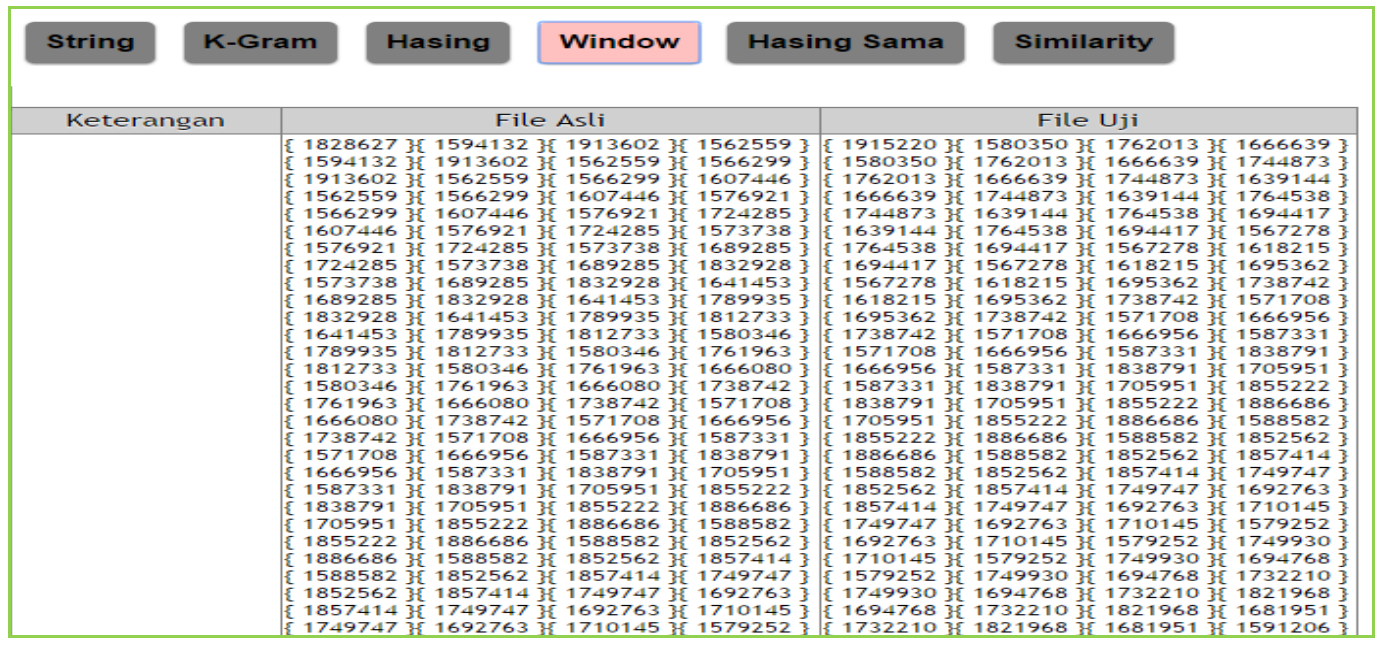

\section{Gambar 7: Tampilan Halaman Windows}

\section{e) Hashing Yang Sama}

Dari hasil hashing pada proses sebelumnya, secara otomatis hasil hash yang memiliki kesamaan akan diberi tanda merah oleh sistem, agar dapat membedakan antara hash yang memiliki kesamaan dengan hash yang tidak memiliki kesamaan. Gambar 8 memperlihatkan tampilan hashing yang sama pada algoritma rabin-karp, sedangkan untuk algoritma winnowing hashing yang sama didapatkan dari window. Nilai window yang paling kecil dari masing-masing baris window adalah yang diambil sebagai nilai hash yang sama. 
yang dibutuhkan. Algoritma Rabin-Karp memiliki akurasi sebesar 37,5\% dengan waktu proses selama 0,19 detik, sedangkan algoritma Winnowing memiliki tingkat akurasi sebesar $88,89 \%$ dengan waktu proses selama 0,13 detik.

Tabel 11. Perbandingan Algoritma Rabin-Karp dan Algoritma Winnowing

\begin{tabular}{lll}
\hline Algoritma & Tingkat Akurasi (\%) & Waktu Proses (detik) \\
\hline Rabin-Karp & 37,50 & 0,19 \\
Winnowing & 88,89 & 0,13 \\
\hline
\end{tabular}

\section{Kesimpulan}

Penelitian ini membuktikan bahwa algoritma Rabin-Karp dan algoritma Winnowing mampu mendeteksi tingkat kesamaan teks dengan level yang berbeda. Penelitian ini juga menggambarkan dan menguraikan tahapan penggunaan kedua algoritma yang diterapkan pada file yang sama. Hasil dari kedua algoritma dibandingkan berdasarkan 2 (dua) variabel yaitu tingkat akurasi dan waktu proses. Hasil percobaan membuktikan bahwa algoritma Winnowing lebih unggul dibandingkan dengan algoritma Rabin-Karp dari kedua variabel yang menjadi landasan perbandingan karena bukan hanya nilai hash saja yang dibandingkan, namun nilai hash yang ada akan dikonversikan terlebih dulu kedalam window baru sehingga dapat diketahui nilai hash yang sama. Aplikasi ini dapat mendeteksi kesamaan dokumen walaupun telah dilakukan perubahan posisi teks dokumen tersebut, meskipun mempengaruhi nilai similarity/persentase kesamaan menjadi turun.

\section{Daftar Pustaka}

[1] Oxford English Dictionary, https://en.oxforddictionaries.com/definition/plagiarism, retrieved 24 April 2018.

[2] Turnitin, https://www.turnitinuk.com/login_page.asp?lang=en_gb, retrieved 27 April 2018.

[3] Plagiarism Checker X. https://plagiarismcheckerx.com/, retrieved 27 April 2018.

[4] Grammarly, https://app.grammarly.com/, retrieved 27 April 2018.

[5] Dupli Checker, https://www.duplichecker.com/, retrieved 27 April 2018.

[6] J. Lin. Brute Force and Indexed Approaches to Pairwise Document Similarity Comparisons with MapReduce. SIGIR. Boston, Massachusetts, USA. 2009.

[7] F. Ture, T. Elsayed, J. Lin. No Free Lunch: Brute Force vs. Locality-Sensitive Hashing for Cross-lingual Pairwise Similarity. SIGIR. Beijing, China. 2011.

[8] G. Sidorov, D. Pinto. Computing Text Similarity using Tree Edit Distance. World Conference on Soft Computing (WconSC). Redmont, WA, USA. 2015.

[9] F. Hofmann. Levenshtein Distance and Text Similarity in Python. http://stackabuse.com/levenshtein-distance-and-text-similarity-in-python/, retrieved 28 April 2018.

[10] L. Salmela, J. Tarhio, P. Kalsi. Approximate Boyer-Moore String Matching for Small Alphabets. Algorithmica. 2010. Vol. 58:591.

[11] N. Ben Nsira, T. Lecrog, M. Elloumi. A Fast Boyer-Moore Type Pattern Matching Algorithm for Highly Similar Sequence. International Journal of Data Mining and Bioinformatics. 2015. Vol. 13(3). pp. 266-288.

[12] B. Leonardo, S. Hansun. Text Documents Plagiarism Detection using Rabin-Karp and Jaro-Winker Distance Algorithms. Indonesian Journal of Electrical Engineering and Computer Science. 2017. Vol. 5, No. 2. pp. 462-471. 
[13] C. Supriyanto, S. Rakasiwi, A. Syukur. A Comparison of Rabin Karp and Semantic-Based Plagiarism Detection. 3rd International Conferences on Soft Computing, Intelligent System and Information Technology (ICSIIT). Bali, Indonesia. 2012.

[14] A. P. Utama Siahaan, Mesran, R. Rahim, D. Siregar. K-Gram as A Determinant of Plagiarism Level in Rabin-Karp Algorithm. International Journal of Scientific and Technology Reserach. 2017. Vol. 6, Issue 07.

[15] R. Sutoyo, I. Ramadhani, A. Dwi Ardiatma, et. al. Detecting Documents Plagiarism using Winnowing Algorithm and K-Gram Method. International Conference on Cybernetics and Computational Intelligence (CyberneticsCom). Phuket, Thailand. 2017.

[16] X. Duan, M. Wang, J. Mu. A Plagiarism Detection based on Extended Winnowing. MATEC Web of Conferences. International Conference on Electronic Information Technology and Computer Engineering (EITCE). Zhuhai, China. 2017. Vol. 128.

[17] K. T. Tung, N. D. Hung, L. T. My Hanh. A Comparison of Algorithms used to Measure the Similarity between Two Documents. International Journal of Advanced Research in Computer Engineering and Technology (IJARCET). 2015. Vol. 4 Issue 4. 